\title{
Analytical Study of the Phenomenon of Money Laundering and its Impact on the Iraqi Banking Sector
}

\author{
Raad Abdulameer Oleiwi \\ Ministry of Finance, Accounting Department, Dhi Qar Treasury Directorate \\ raadalameer5@gmail.com
}

Submission date:- 26/9/2018 Acceptance date:- 4/12/2018 Publication date:- 24/2/2019

Keywords: Money laundering, Financial sector \& Banking sector.

\begin{abstract}
This study discusses the phenomenon of money laundering and its impact on the financial sector in general and the Iraqi banking sector. The research methodology describes money laundering in detail and the three basic stages of money laundering, placement, layering and integration. How and where money laundering is a key reason to address this problem and what is the role of governments? It also deals with the impact of money laundering on the Iraqi economy, which is the theft of banks, the suspension of industrial projects, terrorism and corruption. The most important recommendations that limit this phenomenon is international cooperation and legal assistance in money laundering investigations. The use of programming and electronic systems to enter the information of owners of real estate and businesses to detect suspicious activities. To reduce this problem requires the establishment of specialized units in the Central Bank and the Ministry of Finance, Justice and the security services to apply all laws against money laundering. As for the Iraqi banking sector, it is necessary to verify the identity of the owners of the funds deposited in banks. Inform the competent authorities by the bank's management of any suspicious activity. In addition to confirming the documents proving the legality of the funds deposited.
\end{abstract}

\section{- Introduction}

History reveals that the money laundering is one of the biggest causes of terrorism in many regions around the world and has a major impact on economic growth, and beside this, it is also a threat to the country's overall financial sector reputation. The word "Money Laundering" retrieved from the Mafia" s attempt to lend illegal money in cash form for washing salons in the 1930s in the USA that then controlled by criminal organizations. The IMF (International Monetary Fund) in 2000 presented World Bank" s budget estimations, according to those estimation results, from the world" s overall gross domestic product (GDP), 2 to $4 \%$ money stubbles from money laundering activities. [1] stated that more than $\$ 2.0$ to $\$ 2.5$ trillion amounts across the world generate only by money laundering activities. The world GDP in 2004 was US\$ 500 billion, which raised up to 1 trillion dollars, as recorded approximately 44,444 trillion US\$ in 2006, was an observed figure from the banking sector only.

The Central Bank of Iraq (CBI) has organized a course on combating money laundering, terrorism financing, compliance, and risk management.

The course was held from 17th to 20th September at the Central Bank building, under the supervision of the banking studies center.

Sixty-one employees from the government, private banks, and money transfer companies attended the event.

Iraq occurs in the first place among the riskiest countries in terms of money laundering, according to the Basel Institute on Governance's 2017 edition of the Basel Anti-Money Laundering Index.

This edition is an annual ranking that assesses 146 countries regarding money laundering risks.

The Arab countries with the highest AML risk after Iraq are Jordan, Qatar, Saudi Arabia, Kuwait, Egypt, Bahrain, UAE, Tunisia, Morocco, Algeria, Yemen, and Lebanon.

The report is based on 14 sub-indices that are equally weighted in each country's score among the most dangerous countries. 
The report pointed out that the global average of the index reached 6.15 this year, compared to 5.85 last year, with Jordan achieving a better rate than the world average of 4.90 .

In October 2005, U.S. Congressman Tom DeLay was indicted on money laundering charges, forcing him to step down as House Majority Leader. Money laundering is a serious charge -- in 2001, U.S. prosecutors obtained almost 900 money-laundering convictions with an average prison sentence of six years. The rise of global financial markets makes money laundering easier than ever -- countries with bank-secrecy laws are directly connected to countries with bank-reporting laws, making it possible to anonymously deposit "dirty" money in one country and then have it transferred to any other country for use.

Money laundering happens in almost every country in the world, and a single scheme typically involves transferring money through several countries in order to obscure its origins. In this article, we'll learn exactly what money laundering is and why it's necessary, who launders money and how they do it and what steps the authorities are taking to try to foil money-laundering operations.

\section{1-1 Problem}

Money laundering is considered as a bigger cause of terrorism support in various regions around the world. To discourage criminal activities through this money, many types of research already exist, but my study would mainly focus on Iraq. The current political and economic situation of Iraq approves the bulk money laundering activities and operations in Iraq because it directly influences its economy. Thus, the basic objective of this study is to analyze the "Money laundering and evaluating the role of Iraqi banks".Problem

\section{Theory}

\subsection{Money laundering}

Money laundering can be defined as the process of making illegal gains into legal gains. In other words, we can say making dirty money into clean money. [2] highlighted that the aim of most of the offenders is to earn the financial gains for these kinds of groups by illegal means. This procedure allows offenders to enjoy this illegal act without the threat of being caught. Human trafficking, cyber and other computer crimes, drugs dealing, arms smuggling, illegal sales of cars, prostitution business, bribing and many other illegal activities can generate a huge amount of illegal money which then allows the criminals to bring this money into the financial institution through money laundering. When any of such acts generate money offenders usually tracks a path to transfer this money to a place where it is safe or not in limelight. [3] mentioned that criminals do this by using their sources or by transferring money outside the range of government authorities. To deal with this menace seven of the world's most settled economies named as G-7 created a task force in Paris in 1989. The force was named as the Financial Action Task Force on money laundering (FATF). Out of many tasks, the major task of this force was to provide as many pieces of advice to which these governments should take measures to execute it against money laundering as a priority set agenda.

\subsection{THE 3 STAGES OF MONEY LAUNDERING}

Money laundering is one of the illegal financial activities that businessperson should avoid. In the view of the special task force (Financial Action Task Force), the processing of illegally generated money to impersonate their criminal origin is money laundering. [4] mentioned that this illegal money is generated by white collar crime like embezzlement, organized crime like human trafficking and prostitution, terrorist activities, drugs smuggling, illegal arms dealing and many other illegal acts. In order to educate the businessperson about what actually is money laundering and involves money laundering, we had gathered and portrait 3 steps of money laundering which is recognized by the whole universe.

\subsubsection{Stage 1- Placement}

Placement refers to the transfer of illegal money. It is the first step of money laundering. At this stage, the launderer transfers the illegal money from one place to another and adds it into the financial institution. [5] stated that to implement this illegal act money proceeds in bulk is shattered into pieces so that no legal authorities can detect it. After this, money is injected into a financial institution in many ways. One way to inject money into circulation is by depositing these smaller parts of money proceeds into several bank accounts so that any legal authorities cannot detect any bigger transaction that catches the eye or put the transaction into the suspicious mode. Money orders, deposit cheques, and other financial instrument are purchased and then injected into circulation. Most commonly money is smuggled to those countries where a law against such acts is not strict at all. 


\subsubsection{Stage 2- Layering}

[6] stated that layering refers to creating complex transactions where the separation of illegal money from its origin in done. It is the second step of money laundering. In this process, illicit proceeds are moved several times and to several places. This is done by transferring illicit proceeds from one bank account to another bank account and sometimes from one country to another. Most visited places are those where a law against such illegal acts are not strict or countries which do not follow the recommendations of FATF or countries where AML (anti-money laundering) does not work. With this money, offenders can also buy stock and other financial instruments. In order to make money legal, some criminals buy goods and then sell it to another country. This way of money laundering also refers to as layering.

\subsubsection{Stage 3- Integration}

Induction of illicit money proceeds back into the economy in such a way that it seems to look as a normal business activity refers to as integration. It is the third and final way of money laundering. During this stage money re-enters, the financial institution becoming legal and white again. [7] explained that investment like buying property or expensive items is done in the economy by criminals. Offenders usually purchase or set up organizations, companies in countries with strict rules and regulations. In this way, they can use the money without being caught.

\subsection{Money laundering per year}

Money laundering is a menace and is done by criminals in almost every other country. An estimated amount is displayed in order to provide some information about this major problem. [8] mentioned that an organization in order to find out how much money is laundered by illegal acts like drugs dealing, trafficking and many other criminal activities conducted a research. [9] stated that the organization name was the United Nations Office on Drugs and Crime (UNODC). According to the illegal money around 3.6\% is being smuggled. This estimated is almost around the amount estimated by the International Monetary Fund, in 1998. International monetary fund estimated that around 2 to 5\% of the world gross domestic product could be money laundered. [10] mentioned that the lowest figure that was quoted is almost equal to the output economic size of a city like Spain. Because of its illegal nature proper and detailed results of money laundering are not present and due to this, it is impossible to detect the exact amount of money laundering done worldwide. This is the main reason why FATF could not provide any definite amount.

\section{How is money laundered?}

Illegal money is difficult to deposit in a big amount, so money laundered broke that in small amounts and figures for depositing it into banks. [11] mentioned that money laundering is done to convert the illegal profits into white money. Money laundering occurred in various stages first large amount is converted into small figures. The cash amount that is broken into small figures is then transferred to other accounts by utilizing banks instruments such as pay order, cheques and money order etc.

The second stage occurs when the fund is moved to distant places so that it cannot be tracked easily. [12] mentioned that it is important that the fund should be moved through various channels and for this purposes launderer take various small steps. Launderer used this fund for purchasing of financial instruments and sometimes it is invested in different portfolios. Anti-money laundering jurisdiction imposed differently was and the division and movement of money are operated for keeping cash away from these anti laws. This procedure further involves the diverse accounts in various countries and banks. Money launderers open accounts in different countries with a number of different sources and transferred cash in there that further secure this black money from money laundering trials and jurisdiction. Other than this the movement of cash happens in the money markets for asset purchasing.

[13] mentioned that after passing through the first two stages successfully money launder made it more secured by integration, that is the third stage of moving illegal profit into financial; systems. In this step, cash is being invested in various luxuries and real estate assets. Sometimes business ventures are formed due to the integration of illegal money.

\section{-Where does money laundering occur?}

Money launderer generates money by doing criminal activities without any geographical limitations. [14] stated that it could be done anywhere globally and at the end, money is sent to the money launderer due to which this whole process occurred. The income generates through criminal activities cannot be shown in the appropriate financial system because of accountability so money laundering occurs through stable financial systems for moving that money back to the launderer.

[15] mentioned that geographical terms and infrastructure for investment are keenly observed while criminal and placement activity. It happens in some cases that illegal profit is under layer only in the closed geographical limits 
where this activity occurred, but the possibility of geographical concentration is very low. For making the convenience of placement activity the geographical limitation is very important.

It was stated by [16] that criminal focused on high profile paces for investment that includes offshore companies, any world banking or any good business profile. For money laundering stable and appropriate financial infrastructure has an essential position and role. While placement laundered money is transferred through banks into different accounts without showing the source of the financial proof. Stable financial economies are selected for the money laundering because of lack of investigation of anti-money laundering cases.

While integration if money laundering occurred in less financially stable economies so laundered tried to keep it in small transactions so that it may be safe and away from anti-money laundering investigation.

\section{-Money laundering and its effect on business}

The reliability of banking $g$ and financial services depends on the systems which are being used and whether these systems are an inappropriate working form or not. Legality is one of the most important requirements and if a system is not functioning in legal terms and conditions, it can impact the whole system of a country but especially the business sector. [17] stated that the link of money laundry and business is very deep because people launder only that money which they are making illegally and have to valid proof for the money to be legal. They cannot place that money in one country especially at a place where they are running the illegal activities, so they send it to different countries through money laundering. Money laundry is the worst activity for the reputation of the business sector of a country. [18] explained that people do not only make money through illegal activities, but they use it to fund more illegal activities such as terrorism and others which ruin the peace of a nation. Iraq of one of those countries which have an even still is facing the worst effects of the money laundering especially the macroeconomic factors of the region are being affected the most. One of the most important things for the growth of a business sector is an international investment and because of being a constant target of money launders the country is facing difficulties in finding international investors. Money laundry also affects very badly on the exchange rate of a currency and decrease the value of the currency.

\section{5-1- Effect of money laundering on national income}

Money laundering leads to increased incomes for some groups at the expense of productive groups in society, because these groups receive money laundering. This increase leads to a gap between the strata of society and thus leads to widespread social.

[19] mentioned that the money fleeing abroad during the washing operations represent deductions from the national income, this situation is a drain of the national economy to the external economy. Money smuggled and acquired through crime deprives the country's economy of this money and invests it on its own land and for the benefit of its citizens, with negative consequences. Even if the laundering occurs in an in-kind form of money, this leads to an increase in consumption rates above national income [20]. Consequently, structural economic imbalances occur because of reduced savings and increased consumption. These areas lead to similar growth in GDP.

\section{5-2- Effect of money laundering on currency and exchange rate}

The exchange rate is directly affected in the countries of the source of funds when they exit with the intention of washing, and also affected by the exchange rate in the receiving countries. Where the main benefit of that process for money laundering operators and smugglers.

This effect is classified into two sides as follows:

\section{1 - the effect of smuggling money laundered on the currency and the exchange rate}

According to [21] the process of replacing the national currency obtained from illegal activities with foreign currency. Leading to a devaluation as a result of the increased supply of the national currency against the required foreign exchange. An increase in the local currency with increased demand for foreign currency leads to the depletion of the country's foreign exchange reserves. In this case the financial authority raises the interest rate; to maintain domestic savings from the conversion to other foreign currencies. Raising the interest rate is one of the most important obstacles to investment. In addition, it is causing confusion to the national currency market as a result of the sudden withdrawal of funds by the money launderers from the national banks, in preparation for the cross-border cash transfer, and thus the devaluation. 


\section{2- Effect of the entry of money laundering on the currency and the exchange rate}

According to [22] the entry of illegal foreign exchange funds into the country where the laundering is affected increases foreign cash flows. As it leads to increased demand for national currency, and this leads to raise the price of the national currency more than its real value, which leads to many risks. The most important these risks are:

The value of the national currency has changed so as not to reflect the reality of economic performance. Also, just a change in the direction of the movement of capital, and this harms the national economy, where the competitiveness of prices in the face of foreign goods. Finally, the high price of the national currency without economic justification is an obstacle to the entry of foreign capital, directly or indirectly.

\section{Influence of money laundering has on economic development}

[23] mentioned that Money laundry is one of those international phenomena which have affected the whole world and even after so many precautions and implementation of rules and regulations, it is still happening on a very large ratio. It is a fact that this issue has affected the economy of the world very drastically especially the economy of those countries which are actually being used by money launders. Iraq is one of those regions which can be called a haven for criminal and illegal activities and the reason behind that is not the population of the country or the lack of regulations, it is because it has been vulnerable for a lot of time because it was being stated that terrorist has made it their base.[24] mentioned that money laundry occurs in any country due to a high level of corruption. The rate of corruption in Iraq is very high which has influenced the illegal activities such as money laundering. Smuggling is occurring at a very high level of things like tobacco, Cigarettes, petrol, and another such thing which has again fueled the issue of money launder. Till the year 2014, Iraq was losing at least $\$ 800$ million a week because of the occurrence of money laundry on a high level and in the same year, there was at least $\$ 1.2$ billion of money which was laundered in the region. After remaining in a very bad position economically, Iraq got support from World Bank in 2015 so it the country can build up strong systems again and they also made an anti-money laundry policy in which a person cannot carry more than 10,000 dollars when going out of Iraq.

\section{Role of government in Money Laundering}

[25] highlighted that in the reaction of mounting concern over illicit money being laundered, many governments have developed anti-money laundering programmes. The aim of these programmes is to create awareness about this illicit money smuggling in public and private business sectors and then to give recommendations which the related authorities should take to execute these recommendations in order to stop this menace of money laundering. [26] stated that out of these recommendations one of them is to make money laundering a criminal act, providing detective agencies to track grab and finally impound those assets which are illegally bought and developing the required framework for allowing the agencies associated to interchange the details between themselves and similar sort of information with other countries.

[27] mentioned that the Government should take all the preventive measures to stop this act of money laundering as this affects the country's economy badly. In order to solve this problem, it is very important that the government should gather all the related authorities to one table. The government should bring agencies, financial institutions regulatory authorities and law enforcement institution and private business sections to deal with this problem against financial institutions and as a whole against the country. By the help of these institutions records, transactions can easily be detected.

\section{- Money Laundering in Iraq}

Money laundering is a menace and is a serious criminal activity as it affects the economy of a nation as a whole and individual financial institutions. It is the form of financial criminal activity as it creates a lack of harmony of economic stability, which is necessary for any country to achieve its goals of developing a society, nation-building, and prosperity. [28] stated that due to lack of government policies illicit money in Iraq enters easily without passing through many different stages. Another bigger reason for money laundering entering into Iraq's economy is its security condition and lack of stability which allows criminal offenders to destroy Iraq's economy easily n openly without the fear of being caught. This makes the Iraqi economy unsafe. [29] stated that every year especially in Iraq's central and southern province thousands of cases have been noted where an individual practice the illegal activity of money laundering quite easily. The developments in the financial section have helped these individuals to smuggle funds through online sectors in such a way that detection of it becomes almost impossible. These banking sectors help to complete illicit money transactions in a suspicious way. The Internet is also utilized by these offenders as it is the fastest way to transfer money from one location to another. In a research, it is shown that $25 \%$ of the emails that are sent between these institutions and individuals do not contain details about the transactions. 


\section{-Illegal money sources in Iraq}

Iraq is being stated as the sixth most corrupt countries in all over the world because there are many illegal activities which are occurring in the country. There are many illegal sources of money which are funding the growth of criminal and illegal activities in the country.

[30] stated that the biggest source of illegal money for the criminals of Iraq is the drug trade which is happening at the very high level in the country. Because of being a free zone, drugs can be easily carried in and out of the region. Government bribery is one more source of making illegal money in Iraq and this is something very common in the country. Tax evasion is also fueling the illegal money [31] stated that theft is very common in the region. Along with all that, there are also the issues of illegal trading or smuggling of oil, machinery, equipment, and tobacco and of other such items. There are also fake companies which are manufacturing and selling drugs in Iraq.

\section{- The role of Iraqi banks in money laundering}

There are at least 2000 institutions in Iraq which are working on the financial matters of the country. [32] stated that most of this institution has only one main operation and that is of transferring money from Iraq to other countries so these institutions play an important role in all the financial issues occurring in the country. These institutions have been forbidden to send money out of Iraq, but they are still doing it. It is a fact that in last some years, the supervision of money activities has become somewhat strong in Iraq, but the power is not as much to stop the occurrence of illegal activities like money laundering completely. Before the year 2013, the corruption was very high in the region and in that corruption, many banks were involved as well. [33] mentioned that the laws enforcement organizations working in Iraq has made strong tracking systems in Iraq for financial activities which can halt the Illegal transactions of money, but the compliance capabilities of the banking sector of the region and illegal money exchange organizations have made things complicated for the forces. The banks of Iraq and money exchange companies are prohibited to transfer money especially from the areas which are known as ISIL-controlled areas. The rules and regulations for the banks of Iraq have changed as per the security reasons of the country. [34] mentioned that the private banks now mostly open accounts on the basis of the referrals of those who already have an active account in their regions. Filing an STR is important for the banks of Iraq but it has been observed that very few STR has been filed. The lack of compliance is because of lack of penalties which have unmotivated banks to file STRs. Because there is no fear of penalty, the banks of Iraq do not consider the importance of internal investigation. For years banks are being used for money laundering. [35] stated that to make the illegal money legal, every criminal need to place the money somewhere which signifies legal activities only, so they use banks account for that. [36] stated that there was a time when the bank accounts and activities occurring in them were not being checked but now there are strict rules for that. The reason for the increased ratio of money laundering in the banks of Iraq was the lack of supervision and even now the situation is the same.

\section{- The Central Bank of Iraq}

The central bank of Iraq has the focal position in the banking system of the country and all the other private banks in one way or the other work under the supervision of the central bank of Iraq. The bank takes part in the policy making of the country especially for the banking sector as well as the money exchange organizations [37] stated that the bank also has the power to keep a check over the activities which are occurring in the other private banks. In the last some years, the central bank has played a very significant role to reduce the problem of money laundering. The bank has made the anti-money laundering policies with which the bank is trying to ensure the compliance of other banks as per the policies of banking as well as with the policies of money transfers and transactions. The bank makes the rules and regulation with the help and cooperation of the forces and government to make sure that no illegal activity is occurring with the money. [38] stated that conducting audits of the banks is also the duty of central bank of Iraq to make sure that the money which is being placed in the banks of Iraq is only the legal money and being used only for legal activities. The United Nations Security Council produces a list of organizations and financial institutions that need to be monitored against transactions, the Central Bank of Iraq also provide this list to its financial institutions. Below are the responsibilities of financial institutions to consider while conducting business which are:

- To get the identity of the beneficial owner of the money this is being placed in the bank.

- To get the verification of the customers through proper documentation and requirements

- The banks are obliged to inform the concerned authorities if any account transact more than 15 million Dinars and they need to generate the report.

- They are obliged to report suspicious transactions over 2 million Dinars

Jabbar Abdul Khaliq who was the member of the Iraqi Parliamentary Finance Committee stated that the involvement of banks in the illegal fund transferring and smuggling is a known fact in Iraq and the money is being transferred to the international banks. Most of the banks are also involved in the transfer of money in the form of hard 
money which is based on so-called merchandises and goods. [39] highlighted that there were many accounts which have been checked and it was found that Abdul Khaliq there was no proper verification of the money which was being transacted through those accounts. Most of the accounts were of the sale of merchandises which didn't seem legal. It was also found out that there are banks which are dealing with illegal trade of goods and getting tax from them. [40] mentioned that The Iraqi Parliamentary Finance Committee evaluated that to reduce the idea of money laundering from the country or to even reduce it further, the private banks will be able to involve in the sale of US dollars only twice a month.

\section{Money laundering effects on Iraq's economy}

The problem of money laundering is proving to be the worst for the economic growth of Iraq and because of the unresolved issue of money laundering; the region is facing many issues.

\subsection{WEAK NATIONAL INCOME}

[41] mentioned that the money laundering which is happening in Iraq is decreasing the value of the national income. It is quite understood that if money laundering is occurring in a country in so big ratio, the outsiders will think that the country has black money mostly. The robbery of banks of Iraq has also weakened the income national income of the country.

\subsection{SUSPENSION OF INDUSTRIAL PROJECTS}

[42] highlighted that because of the increased money laundering and many other criminal activities, many products have been stopped. There were some projects which were closed because of the lack of money because almost all the money is being smuggled to different countries. Smuggle of the capital caused a lack of balance between savings and consumptions.

\subsection{MONETARY INSTABILITY}

[43] mentioned that because the money in Iraq has no security and power, so most of the people who are earning the money legally like to invest in other countries so that they can increase the value of their money and gain benefit from it which does not seems possible in the current situation of Iraq,

\subsection{SOCIAL IMPACTS}

[44] explained that the negative impacts of money laundering in the economy of the country have been analyzed but the problem is impacting negatively on the country socially as well. The social effects of money laundering are below:

- It has ruined the social relationships in the country

- The problem of money laundering has raised many unethical issues

- People both men and women and even children are being kidnapped.

- It has destroyed the infrastructure of the country very badly.

- Because of the lack of investments, there is a lack of employment and it has caused a rise in the ratio of poverty.

- The lifestyle of the nation of Iraq is not very high.

- Increase in bribery, corruption, and social crimes.

\section{Results}

The depth study of the phenomenon of money laundering shows the extent of this problem and its negative effects in all areas of life. It is a devastating and catastrophic phenomenon that is seriously damaging the economy and destroying the confidence of society in the financial sector.

Must be addressed by all means and face firmly, and therefore can be summarized the most important results of this study as follows:

1.There is a close correlation between the emergence of the problem of money laundering in the world and the phenomenon of globalization, which is exploited by some to hit the financial sectors.

2.Technological progress is being exploited in a variety of ways of spreading money laundering. Using advanced means such as the use of the Internet, ATM cards and satellite communication technology in money laundering operations.

3.Money laundering the process of mixing money illegally obtained in the economic cycle to show that it is legitimate money (clean money).

4.The existence of competition between banks led to the encouragement of owners of illegal capital to open accounts and cover them by these banks. These measures are carried out by some employees or bank departments to raise the 
level of profitability. This action leads to the collapse of national economic security because it is money from illegal sources (financial corruption or terrorism).

5.There is a global interest in each country to reduce the phenomenon of money laundering. This is done through legislation, laws, regulations and financial control institutions. There are no measures that limit this phenomenon in Iraq.

6.The absence of political stability leads to the spread of the phenomenon, where these areas are characterized by the presence of money laundering centers.

7.Money laundering is a risk factor for confidence in the financial sector. In addition to the risks to the financial markets, which requires a high degree of transparency and achieve the hypothesis of the efficiency of the financial market.

\section{Following are the most important results in Iraq:}

1- The phenomenon of money laundering in Iraq newborn, but it is growing rapidly because of the internal and external environment of this phenomenon.

2 - The absence of laws and legislation that limit this phenomenon in Iraq.

3. Lack of institutions to limit this phenomenon.

4 - The drug trade topped the world's money laundering, while in Iraq it was to steal banks and financial corruption ranked first.

5 - The exposure of the Iraqi market has also contributed to the laundering of money in Iraq. Through the opening of borders with neighboring countries and without any security, financial, administrative or legal obstacles.

\section{4- Recommendations}

Working to get rid of the phenomenon of fictitious banks that play a hidden role in money laundering, this work includes opening regional and international banks in the country. These banks are subject to the regulations and regulations applicable in the country. In addition to canceling any license a bank involved in money laundering or terrorist financing.

Use of programming and electronic systems to enter the information and data of real estate owners and land in the field of real estate registration and government real estate services. To detect the perpetrators of the crime of financial and administrative corruption and money launderers.

Increase international cooperation and legal assistance in investigations and prosecutions related to money laundering.

The development of the laws of the confidentiality of bank accounts. Also training employees in banks and financial institutions on modern methods to detect attempts to launder money and report on these operations.

Take advantage of the experiences of developed countries in eliminating money laundering operations.

The elimination of the phenomenon of money laundering requires appropriate measures to reduce the effects of this kind of illegal activities because it harms the Iraqi economy. Through the establishment of specialized units in the Central Bank, the Ministry of Finance, Justice and the security services so that they all apply the law against money laundering.

\section{- Conclusion}

The idea of money laundry is very common all over the world and it has been concluded that it is occurring in the countries mostly which are vulnerable, economically politically as well as geographically. It has been evaluated that money laundry occurs when people try to send their money out of the border which they have earned from illegal and criminal activities. It has also been evaluated that Iraq has been affected by the money laundry for years now. The value of the economy of Iraq is going down fast because of the high ratio of money laundry in the country. The reason for money laundry in Iraq is the high level of corruption and involvement of banks of Iraq in that corruption. The government and the central bank of Iraq have made strict policies for anti-money laundering from the country to be followed by the banks as well as other population but there is a lack of compliance. People and even financial institutions are not taking these police seriously because there are not strict penalties for that. 


\section{CONFLICT OF INTERESTS \\ There are no conflicts of interest.}

\section{References}

[1] Agarwal, J. D and Aman Agarwal, Globalization and international capital flows, Finance India, Vol. 19/1, pp. 6599. 2004.

[2] Le-Khac, N.A., Markos, S., O'Neill, M., Brabazon, A. and Kechadi, T., An efficient search tool for an anti-money laundering application of an multi-national bank's dataset. p.p (32). 2016.

[3] Colladon, A.F. and Remondi, E., Using social network analysis to prevent money laundering. Expert Systems with Applications, 67, pp.49-58. 2017.

[4] Primorac, D., Miletic, N. and Pilic, M., Safety and legal framework on preventing of use of the financial system for money laundering according to solutions of the directive (EU) 2015/849. In Economic and Social Development (Book of Proceedings), 31st International Scientific Conference on Economic and Social (p. 67). 2018.

[5] Demetis, D.S., Fighting money laundering with technology: A case study of Bank X in the UK. Decision Support Systems, 105, pp.96-107. 2018.

[6] Frankel, T. and Laby, A.B., The regulation of money managers: mutual funds and advisers (Vol. 3). Wolters Kluwer Law \& Business. 2015.

[7] Chaikin, D., Money Laundering and Tax Evasion-The Assisting of the Banking Sector. In the Handbook of Business and Corruption: Cross-Sectoral Experiences (pp. 237-254). Emerald Publishing Limited. 2017.

[8] Shahin, W. and El-Achkar, E., Banking and Monetary Policies in a Changing Financial Environment: A Regulatory Approach. Routledge. 2016.

[9] Chong, A. and Lopez-De-Silanes, F., Money laundering and its regulation. Economics \& Politics, 27(1), pp.78-123. 2015.

[10] Masciandaro, D. ed., Global financial crime: terrorism, money laundering, and offshore centers. Taylor \& Francis. 2017.

[11] Gilmour, N., Understanding the practices behind money laundering-A rational choice interpretation. International Journal of Law, Crime, and Justice, 44, pp.1-13. 2016.

[12] Naheem, M.A., Trade-based money laundering: towards a working definition for the banking sector. Journal of Money Laundering Control, 18(4), pp.513-524. 2015.

[13] Christopher, C.M., Whack-A-Mole: Why Prosecuting Digital Currency Exchanges Won't Stop Online Money Laundering. Lewis \& Clark L. Rev., 18, p.1. 2014.

[14] Hopton, D. Money laundering: A concise guide for all business. Gower. 2016.

Ismael, J.S. and Ismael, T.Y., Iraq in the twenty-first century: regime change and the making of a failed state. Routledge. 2015.

[15] Christopher, C.M., Whack-A-Mole: Why Prosecuting Digital Currency Exchanges Won't Stop Online Money Laundering. Lewis \& Clark L. Rev., 18, p.1. 2014.

[16] Hendriyetty, N. and Grewal, B.S., Macroeconomics of money laundering: effects and measurements. Journal of Financial Crime, 24(1), pp.65-81. 2017.

[17] Rose-Ackerman, S. and Palifka, B.J., Corruption, Organized Crime, and Money Laundering. In Institutions, Governance and the Control of Corruption (pp. 75-111). Palgrave Macmillan, Cham. 2018.

[18] Masciandaro, D. ed., Global financial crime: terrorism, money laundering, and offshore centers. Taylor \& Francis. 2017.

[19] Abbas, S.S. and Ismail, N.B., Anti-Corruption Strategies in Iraq after 2003: The Challenges Ahead. The Social Sciences, 12(11), pp.2191-2199. 2017.

[20] Shahin, W. and El-Achkar, E., Banking and Monetary Policies in a Changing Financial Environment: A Regulatory Approach. Routledge. 2016.

[21] Shahin, W. and El-Achkar, E., Banking and Monetary Policies in a Changing Financial Environment: A Regulatory Approach. Routledge. 2016. 
[22] Abbas, S.S. and Ismail, N.B., Anti-Corruption Strategies in Iraq after 2003: The Challenges Ahead. The Social Sciences, 12(11), pp.2191-2199. 2017.

[23] Villa, E., Misas, M.A. and Loayza, N.V., Illicit activity and money laundering from an economic growth perspective: a model and an application to Colombia. The World Bank. Pp-11. 2016.

[24] Shahin, W. and El-Achkar, E., Banking and Monetary Policies in a Changing Financial Environment: A Regulatory Approach. Routledge. 2016.

[25] Alexander, R.C.H., Insider dealing and money lau 186 the EU: law and regulation. Routledge. 2016.

[26] Chaikin, D., Money Laundering and Tax Evasion-The Assisting of the Banking Sector. In The Handbook of Business and Corruption: Cross-Sectoral Experiences (pp. 237-254). Emerald Publishing Limited. 2017.

[27] Liss, C. and Sharman, J.C., Global corporate crime-fighters: Private transnational responses to piracy and money laundering. Review of International Political Economy, 22(4), pp.693-718. 2015.

[28] NYtimes,. Iraq: Report on Money-Laundering. https://www.nytimes.com/2012/10/31/world/middleeast/iraqreport-on-money-laundering.html. 2012.

[29] Choo, K.K.R., Cryptocurrency and virtual currency: corruption and money laundering/terrorist financing risks. In Handbook of Digital Currency (p.p. 283-307). 2015.

[30] Young, M.A., The transnational organized crime monthly briefing, May 2015: Fighters from Caribbean traveling to fight with extremists in Syria and Iraq. Open Briefing. Pp-22. 2015.

[31] Ryder, N., Out with the old and... in with the old? A critical review of the Financial War on Terrorism on the Islamic State of Iraq and Levant. Studies in Conflict \& Terrorism, 41(2), pp.79-95. 2018.

[32] Shahin, W. and El-Achkar, E., Banking and Monetary Policies in a Changing Financial Environment: A Regulatory Approach. Routledge. 2016.

[33] Alhafidh, M.A.K., Effects of Money Laundering on Iraq's Economy (Doctoral dissertation, Eastern Mediterranean University (EMU)-Doğu Akdeniz Üniversitesi (DAÜ). 2015.

[34] Amina al-Dahabi, Private Banks Investigated for Money Laundering. [Accessed on 25 July 2018]. Available at: http://www.iraq-businessnews.com/2014/12/07/private-banks-investigated-for-money-laundering/.2014.

[35] Omar al-Shaher,. Money Laundering Estimated "in the Billions". [Accessed on 25 July 2018]. Available at: http://www.iraq-businessnews.com/2013/08/23/money-laundering-estimated-in-the-billions/.2013.

[36] John Lee,. Iraq "Not Making Sufficient Progress" on Money Laundering. [Accessed on 25 July 2018]. Available at: http://www.iraq-businessnews.com/2015/07/02/iraq-not-making-sufficient-progress-on-money-laundering/.2015.

[37] Alsaif, K, I and Ramo, R, M. The Role of Banks in Reducing the Phenomenon of Money Laundering. [Accessed on 25 July 2018]. Available at:<https://www.ijcaonline.org/archives/volume180/number17/alsaif-2018-ijca916386.pdf>.2018.

[38] Maitha Al Hashimi,. Iraq's New Draft Anti-Money Laundering Law. https://www.tamimi.com/law-updatearticles/iraqs-new-draft-anti-money-laundering-law/.2015.

[39] Lee, A.,. Asia's anti-money laundering focus sharpens. Int'1 Fin. L. Rev., 34, p.12. 2015.

[40] Kingah, S. and Zwartjes, M.,. Regulating money laundering for terrorism financing: EU-US transnational policy networks and the financial action task force. Contemporary Politics, 21(3), pp.341-353. 2015.

[41] Abbas, S.S. and Ismail, N.B.,. Anti-Corruption Strategies in Iraq after 2003: The Challenges Ahead. The Social Sciences, 12(11), pp.2191-2199. 2017.

[42] Amiri, H., Karim, M.H., Toussi, A. and Javanmard, R., Impact of Economic Transparency on Economic Growth in the Middle East countries. International Journal of Business and Development Studies, 9(2), pp.115-138. 2017.

[43] Abdel Aziz, T., Abbassi, A., Chehade, N. and Lauer, K., The Legal and Regulatory Framework for Microfinance in Iraq. Pp (2). 2015.

[44] John Lee. Iraq "Not Making Sufficient Progress" on Money Laundering. [Accessed on 25 July 2018]. Available at: http://www.iraq-businessnews.com/2015/07/02/iraq-not-making-sufficient-progress-on-money-laundering/.2015. 
تناقث هذه الدراسة ظاهرة غسيل الأموال وأثزها على القطاع المالي بشكل عام والقطاع المصرفي العز اقي بشكل خاص حيث توضح

منهجية البحث عملية تبيض الأمو ال بالتفصيل و المر احل الأساسية الثلاثة المتمثلة في غسيل الأموال التوظيف، التمويه ومرحلة الدمج. كيف و وأين يتم

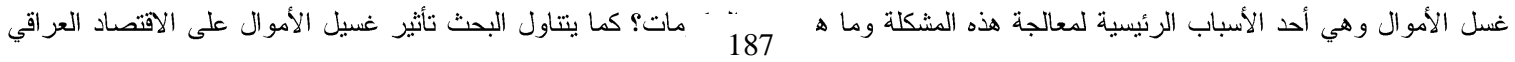

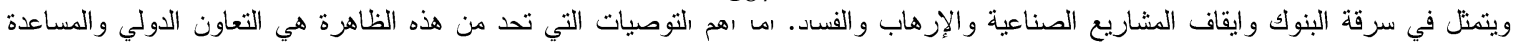

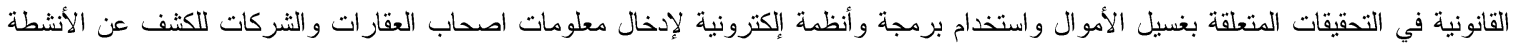
المشبوهة. وللحد من هذه المشكلة ينطلب إنشاء وحدات متخصصة في البنك المركزي ووزارة المالية و العدل والسلطات الأمنية لتطبيق جميع القو انين ضد غسيل الأموال. أما بالنسبة للقطاع المصرفي العراقي، فمن الضروري التحقق من هوية اصحاب الأموال المودعة في البنوك وإيلاغ الجهات

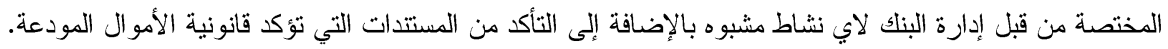

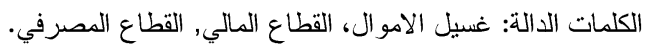

